\title{
BESZÁMOLÓ A REGIONAL STUDIES ASSOCIATION 2010. ÉVI NEMZETKÖZI KONFERENCIÁJÁRÓL
}

\author{
(MTA Regionális Kutatások Központja, Pécs, 2010. május 24-26.)
}

\section{KOVÁCS SÁNDOR ZSOLT}

A Regional Studies Association (RSA), Európa egyik vezető regionális tudományi szervezete minden évben megrendezi éves nemzetközi konferenciáját, az idei a sorban a 19. ilyen rendezvény volt. A 2010. évi esemény rendezési-, szervezési jogát az MTA Regionális Kutatások Központja nyerte meg, így a 2010. évi RSA konferencia Európa Kulturális Fővárosában, Pécsett zajlott május 24. és 26. között az Európa Kulturális Fővárosa program részeként a Pécs2010 Menedzsment Központ Kht. támogatásával. A konferencia szervezésében a Magyar Regionális Tudományi Társaság (MRTT) és a Pécsi Tudományegyetem Közgazdaságtudományi Kara (PTE KTK), mint társrendezők vettek részt, a tanácskozás helyszínéül a „Pécsiközgáz”, illetve a PTE Állam- és Jogtudományi Karának épületegyuittese szolgált.

A konferencia az RSA történetének eddigi legnagyobb rendezvénye volt a résztvevők számát tekintve, az eseményre 575 regionalista tudós, szakpolitikus, fiatal kutató és $\mathrm{PhD}$. hallgató regisztráltatta magát (a korábbi rekordot a 300 fỏ részvételével zajló prágai konferencia tartotta) közel 50 ország képviseletében. A résztvevők között voltak az Európai Bizottság, az OECD és az ENSZ képviselöi is. Legnagyobb számban a hazai szakértők jelentek meg az eseményen, az elhangzott 436 elỏadásból 83-at magyar tudósok, fiatal kutatók tartottak. Kiemelhetô, hogy Európán kívül, a keletázsiai országokból (Kína, Szingapúr), Észak- és Dél-Amerikából, valamint Ausztráliából is érkeztek elỏadók a háromnapos eseményre. A négy plenáris ülés mellett 130 tematikus szekcióuilés segítette a hasonló területeken tevékenykedők találkozását, együttgondolkodását, a különböző elképzelések szintetizálását. A szekcióülések nagy száma árulkodik egyben azok széles tematikai spektrumáról is, melyből a teljesség igénye nélkül csak néhányat kiemelve terítékre került a területi együttmúködések kérdése, a területi tervezés, a városfejlesztés, az innovációk földrajza, a pénzügyi központok területisége, továbbá a regionális tudomány gyakorlati megközelítése.

A Regionális válaszok és globális eltolódások: szereplók, intézmények és szervezetek (Regional Responses and global Shifts: Actors, Institutions and Organisations) konferenciacím megfelelően tükrözi az idén kitüzött célokat: a tanácskozás résztvevői elsősorban arra keresték a válaszokat, hogy a nemzetközi válságból való kilábaláshoz milyen eszközökre és intézményekre van szükség a régiókban, illetve a településrendszerek fejlesztésének milyen irányai képzelhetök el. Az alcím sem elhanyagolható - szereplők, intézmények és szervezetek -, ez irányítja rá a figyelmet a regionális politikában 
eddig végbement és a továbbiakban szükséges változásokra. Napjainkban egyre szélesebb körben foglalkoznak a regionalizmussal, az intézményi keretek mellett ez az irány már a magánvállalkozások szférájában is megjelent. A továbbiakban tehát szükség van ezen szervezetek együttmüködésére, a konszenzus megtalálására. A RSA 2010. évi konferenciája ezt a célt is szolgálta, mint azt David Bailey, az RSA elnöke is kihangsúlyozta nyitóbeszédében.

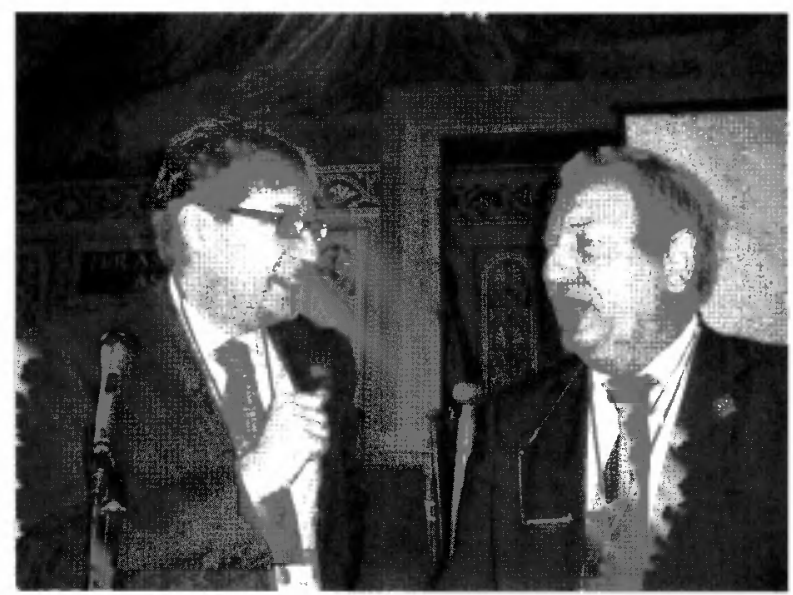

David Bailey, RSA elnök és Dirk Ahner

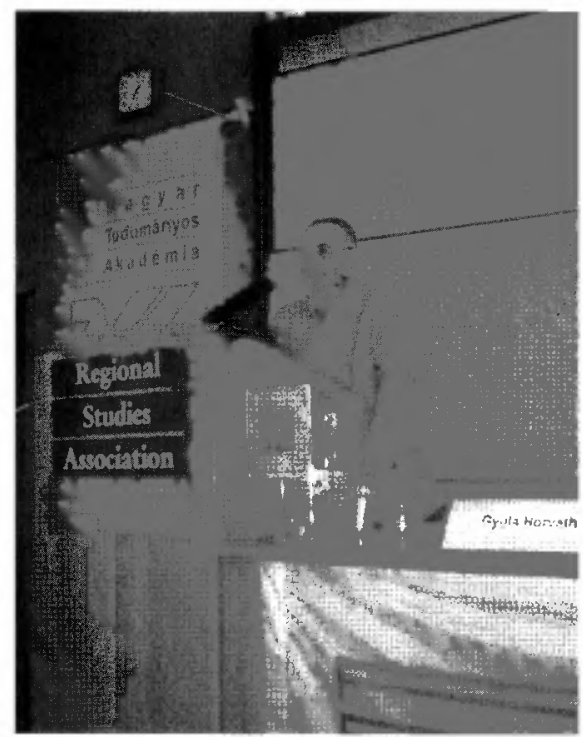

Horváth Gyula, MTA RKK, igazgató; MRTT, elnök

Az MTA Regionális Kutatások Központjának igazgatója, a Magyar Regionális Tudományi Társaság elnöke, Dr. Horváth Gyula köszöntöjében arra hívta fel a figyelmet, hogy az európai fejlödés jövőjének stratégiájához a regionális tudomány a kontinens szinte valamennyi országában kínál megoldási alternatívákat. A konferenciát 
nyitó plenáris ülésen a köszöntők mellett az európai kohéziós politika és annak jövöje volt a téma, melyben hazánk érintettsége is vitathatatlan, hiszen az Európai Unió 2011-es magyar elnöksége idején kell elfogadni az új, hosszú távú európai regionális kohéziós dokumentumot. Az ülésen a kohéziós politika jövőjéről, reformjáról, az új irányvonalakról (pl. „okos” növekedés) Dirk Ahner (Európai Bizottság, Regionális Politikai Föigazgatóság) és John Bachtler (Strathclyde Egyetem) fejtette ki nézeteit, majd a kohéziós politika gyakorlati oldalát Magyarország példáján Heil Péter (MEH) mutatta be. Dirk Ahner Föigazgató Úr a reform tartalmát illetően elmondta, hogy változások várhatók a válság folyományaként, de azok az intézményrendszert, a forrásokat és a szabályozást nem érintik.

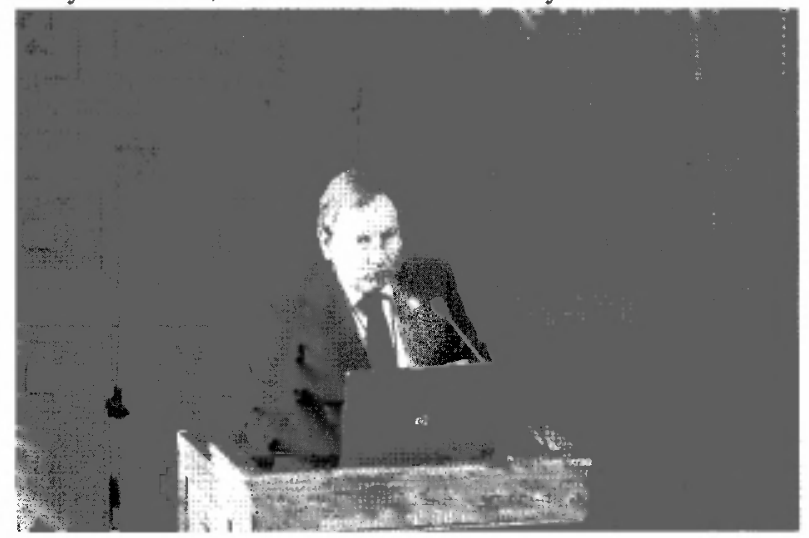

Dirk Ahner, Európai Bizottság,

Regionális Politikai Föigazgatóság, fóigazgató

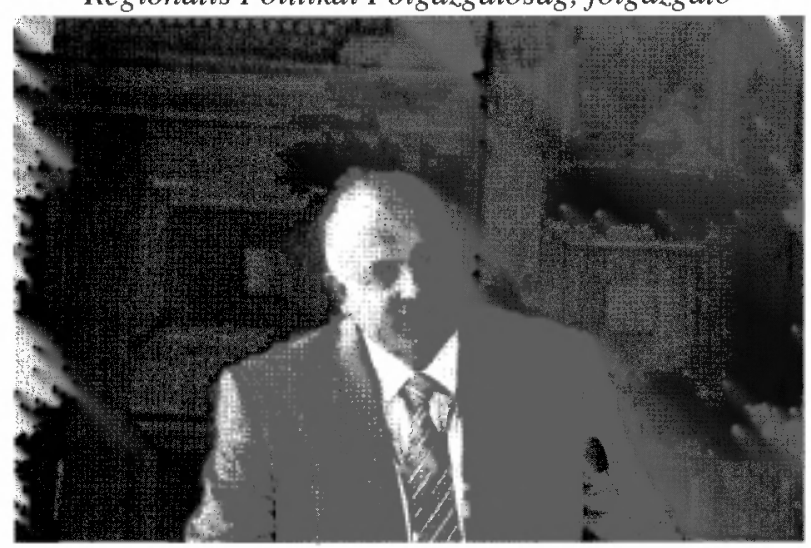

John Bachtler, Strathclyde Egyetem

A második plenáris ülésen a regionális politika lehetőségeiről, s Európán kívüli megvalósulási formáiról hallgathattak előadásokat a résztvevők. A már említett, földrajzi szempontból széles körü érdeklődésnek köszönhetően egy-egy előadás hangzott el az ausztrál (Andrew Beer), a kelet-ázsiai (Henry Yeung), az amerikai (Mark Partridge) és a dél-afrikai (Ivan Turok) regionalizmusról. Ezután, szintén a 
konferencia második napján sorra kerülö harmadik plenáris ülésen az új európai térrel ismerkedhetett meg a hallgatóság - Grzegorz Gorzelak prezentálásában.

A tanácskozás záróülésén (Place, Cities and Regions) a várostudományok és a területi irányítási politika változásai kerültek előtérbe, de felmerültek olyan, összetett konfliktusforrásként szolgáló problémák is, mint a környezettudatosság, vagy a fenntartható fejlődés. A záró elöadást Ruzsa Csaba, az Európa Kulturális Fővárosa program igazgatója tartotta, a téma természetesen a város és a kultúra szerepe, az EKF program és annak eredményei volt. A záró plenáris ülés részeként megtörtént a legjobb konferencia-tanulmányok díjazása, az elismerést a következỏ kutatóknak ítélték oda:

- Abdelillah Hamdouch - Marc-Hubert Depret (Multiscalar Clusters and Networks as the Foundations of Innovation Dynamics int he Biopharmaceutical Industry)

- Tobias Schulz - Daniel Baumgartner (Civic Engagement - Odds or Obstracle for Entrepreneurship in Rural Areas)

- Andreas Faludi (The Process Architecture for EU Territorial Cohesion Policy)

A legjobb fiatal kutatói prezentáció díját pedig Lena Mäusezahl érdemelte ki „Spinning the Threads: Hybrid Organisations as Creative Intermediaries Negotiating Public, Private and Cultural Values" címü tanulmányával.

A háromnapos konferencián több mint 100 kisebb workshop segítette a résztvevőket tudományos tevékenységük és kutatásaik bemutatásában, szakmai kapcsolataik építésében. Az ezeken a téma-specifikus összejöveteleken kialakult vitáknak, problémafelvetéseknek az eredményeként kerülhettek elötérbe olyan új kutatási irányok, mint a szolgáltatások, a pénzügyek globális földrajza, az offshoring; az innováció és annak területi különbségekre gyakorolt hatása; az iparfejlődés új elemei; valamint a fenntarthatóság kérdései.

A májusi rendezvény megszervezése és lebonyolítása során az MTA Regionális Kutatások Központjának folyamatosan lehetősége volt arra, hogy tudományos eredményeit, tudományszervező képességét megmutassa, bizonyítsa tevékenységének kiváló minőségét. Ennek köszönhetően a magyar regionális tudomány, a Regionális Kutatások Központja a nemzetközi tudományos élet elismert szereplöjévé lépett elö. A konferencia elöadásaiból levont következtetések új perspektívákat, nemzetközi együttmüködési hálózatokat körvonalaznak a regionális tudományok területén.

A visszajelzések szerint hazánkról, illetve Pécsről a konferencia-résztvevök körében pozitív kép alakult ki. Szintén elismeréssel szólt mindenki a kelet- és dél-európai regionális kutatók számára felajánlott konferenciatámogatásról, mely elösegítette számos román, szerb, szlovák és orosz fiatal regionalista részvételét az eseményen.

A szakma mellett természetesen különböző kulturális, gasztronómiai programok is várták a konferencia résztvevöit. A rendezvény előestéjén pécsi városnézésre volt lehetőség, ahol az építészeti remekmüvek (Dzsámi, Székesegyház) mellett a állandó múzeumi tárlatok (Zsolnay, Csontváry) mellett olyan, az EKF program keretében zajló időszaki kiállítások megtekintésére is mód volt, mint a Munkácsy Trilógia, vagy az Alfons Mucha kiállítás. A esték oldott hangulatú beszélgetésekre adtak lehetőséget, hétfőn a Palatinus Hotelben, kedden pedig az Egyetem épületében zajló vacsorákkal, 
valamint ugyancsak kedden az érdeklödök Villányba is ellátogathattak, ahol borkóstoló és vacsora várta őket.

Összességében elmondható, hogy egy igen színvonalas, szakmai szempontból rendkívül hasznos rendezvényen vagyunk túl, s tudván, hogy ez egyben az RSA negyed évszázados történetének legnagyobb konferenciája volt, nemcsak tapasztalatokkal gazdagodva, de büszkén is várhatjuk a folytatást. A szervezet következő éves konferenciájának helyszíne Newcastle városa lesz 2011. április 18. és 20. között. 
Tér és Társadalom 24. évf. 2010/2. 147-152. p.

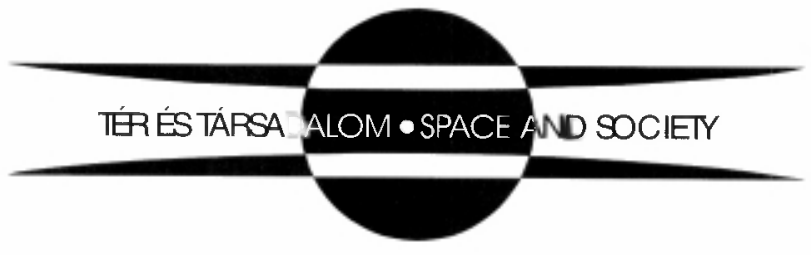

